\title{
СОЦИАЛЬНОЕ ПРЕДПРИНИМАТЕЛЬСТВО: СОЦИАЛЬНО- ЭКОНОМИЧЕСКАЯ ОСНОВА И НАПРАВЛЕНИЯ РАЗВИТИЯ В РЕСПУБЛИКЕ БЕЛАРУСЬ
}

\author{
Е.В. Ванкевич, К.И. Краенкова*
}

Определены объективные предпосылки развития социального предпринимательства, выделены этапы становления инфраструктурной поддержки социального предпринимательства в Республике Беларусь. Проанализирована динамика численности социально незащищенных слоев населения как социальной базы развития социального предпринимательства, определены особенности их поведения на рынке труда. Разработаны направления развития социального предпринимательства в Республике Беларусь. Их реализация обеспечит формирование экосистемы социального предпринимательства и дальнейшее развитие нормативно-правовых основ его деятельности.

Ключевые слова: социальное предпринимательство, социально незащищенные слои населения, экосистема социального предпринимательства.

JEL-классификация: J1, J4, J7, H7.

DOI: $10.46782 / 1818-4510-2020-4-52-65$

Материал поступил 25.05.2020 г.

На протяжении столетий государству отводилась главная роль в вопросах реализации социальной политики. Однако государство не является идеальным инструментом решения общественных проблем и задач, оно выступает главным регулятором в координации данных вопросов (Зайцев, Козел, Титок, 2018. С. 47). Радикальные изменения, провалы рынка, экономический кризис, инертное развитие социальных структур по сравнению с динамикой самого общества, низкая эффективность государственной политики, несвоевременная реализация поставленных задач способствуют появлению различных проблем, в том числе социальных. Перечисленные трудности государство не в состоянии решить без помощи сторонних структур: благотворительных организаций, представителей предпринимательства и т. д. Данные обстоятельства привели к развитию нового подхода к ведению бизнеса, который стал известен как «социальное предпринимательство». Социальное предпринимательство многогранно, его субъекты решают социальные проблемы и достигают социальные цели посред- ством разных бизнес-инструментов. В зависимости от направления социальной деятельности организации и способов получения прибыли от этой деятельности выделяют различные виды социального предпринимательства (Ванкевич, Краенкова, 2018. С. 7), что усложняет процесс определения их субъектов и требует универсального и унифицированного подхода.

Проблема развития института социального предпринимательства начала активно обсуждаться в Республике Беларусь с 2009 г. В 2017 г. в НИИ труда Министерства труда и социальной защиты Республики Беларусь по заданию Правительства Республики Беларусь выполнена научно-исследовательская работа на тему 06.17.01 «Разработать научно обоснованные предложения по развитию социального предпринимательства в Республике Беларусь». По итогам исследования разработан документ, в котором отражены правовые основы социального предпринимательства, проведена классификация и выделены направления деятельности субъектов с учетом белорусской практики. В Республике Беларусь постоянно проводятся фору-

* Ванкевич Елена Васильевна (vankevich_ev@tut.by), доктор экономических наук, профессор, Витебский государственный технологический университет (г. Витебскк, Беларусь);

Краенкова Кристина Игоревна (Kristina-zhavrnk@rambler.ru), Витебский государственный технологический университет» (г. Витебск, Беларусь). 
мы, круглые столы, на которых обсуждаются вопросы социального предпринимательства. В 2019 г. разработан проект Концепции Закона «О социальном предпринимательстве в Республике Беларусь». Таким образом, создан нормативно-правовой задел для становления института социального предпринимательства в стране. Однако для его успешного развития на современном этапе необходимо решить ряд новых задач: разработать систему отнесения организации к субъекту социального предпринимательства, определить координирующий орган, обосновать содержание формы отчетности субъекта социального предпринимательства, необходимой для получения государственной поддержки, и пр. Данные вопросы требуют глубокой теоретической проработки, поскольку сегодня не сложилось однозначной системы признания организации субъектом социального предпринимательства, не определены его социальная база и критерии идентификации, что затрудняет определение направлений и форм его государственной поддержки. Цели государственной поддержки субъектов социального предпринимательства хоть и обширны, но имеют разрозненный характер, «распылены» между различными органами управления. Решением представленной проблемы может служить формирование экосистемы социального предпринимательства с последовательным описанием этапов, определением состава социально незащищенных слоев населения (CHCH) как его социальной базы и формированием нормативно-правового документа, регулирующего вопросы деятельности субъектов социального предпринимательства. Все это позволит сформировать эффективно функционирующий институт социального предпринимательства, который принесет максимальную отдачу всем заинтересованным участникам.

\section{Развитие инфраструктурной поддержки социального предпринимательства в Республике Беларусь}

Появление социального предпринимательства (СП) в Республике Беларусь датируется 70-ми годами XX в. и связано с деятельностью организаций, которые создавали рабочие места для лиц с ограничен- ными возможностями. Эти специализированные коммерческие организации функционируют в настоящее время (например, УП «Светоприбор», УП «Светотехника» и другие организации, входящие в общественные объединения «Белорусское общество инвалидов» и «Белорусское общество инвалидов по зрению»). В начале XXI в. в экономике Республики Беларусь стали появляться отдельные элементы инфраструктурной поддержки социального предпринимательства, что позволяет выделить в его развитии несколько этапов (табл. 1).

Период с 70-х годов XX в. до начала 2000-х годов можно считать первым этапом развития социального предпринимательства в республике, связанным с активной политикой государства в области социальной интеграции и трудоустройства людей с ограниченными возможностями.

В 2009 г. в Беларуси был создан портал о социальной экономике ${ }^{1}$, который стал началом второго этапа в становлении института социального предпринимательства. Он успешно функционирует в настоящее время и представляет собой сочетание новостей и событий о социальном предпринимательстве, информационную базу субъектов, пропагандирующих социальную деятельность. В 2011 г. была запущена первая краудфандинговая платформа «Мае сэнс» ${ }^{2}$. Цель ее деятельности - сбор средств для реализации социальных проектов, а главная особенность - сбор средств и распространение социальных инвестиций. Сервис успешно функционировал более 7 лет, собрал более 1000000 долл. США и реализовал более 500 проектов. В 2018 г. проект был закрыт по решению учредителя. Активная деятельность субъектов позволила сформулировать характерные особенности второго этапа становления социального предпринимательства в Республике Беларусь: информационное продвижение социальных инициатив и расширение возможности получения социальных инвестиций за счет частного сектора. Данный этап решил одну из главных проблем, сдерживающих развитие социального предпри-

\footnotetext{
1 URL: http://soccoop-by.info

2 URL: www.maesens.by
} 
Этапы развития инфраструктурной поддержки социального предпринимательства в Республике Беларусь

\begin{tabular}{|c|c|c|c|c|}
\hline Период & Этап & Решаемая задача этапа & Мероприятия этапа & Ограничения этапа \\
\hline $\begin{array}{l}70 \text {-е гг. XX в. - } \\
\text { конец } 2000 \text { гг. } \\
\text { XXI в. }\end{array}$ & $\begin{array}{l}\text { Зарождение } \\
\text { основ СП }\end{array}$ & $\begin{array}{l}\text { Помощь } \\
\text { в трудоустройстве } \\
\text { людей с ограниченными } \\
\text { возможностями }\end{array}$ & $\begin{array}{l}\text { Создание первых } \\
\text { специализированных } \\
\text { организаций, } \\
\text { трудоустраивающих } \\
\text { лиц с ограниченными } \\
\text { возможностями }\end{array}$ & $\begin{array}{l}\text { Отсутствие поддержки } \\
\text { для СНСН, кроме людей } \\
\text { с ограниченными } \\
\text { возможностями; } \\
\text { низкая узнаваемость } \\
\text { среди стейкхолдеров; } \\
\text { отсутствие программ } \\
\text { инвестирования } \\
\text { для развития СП } \\
\end{array}$ \\
\hline 2009-2011 гг. & $\begin{array}{l}\text { Информа- } \\
\text { ционная } \\
\text { поддержка }\end{array}$ & $\begin{array}{l}\text { Информационное } \\
\text { продвижение социальных } \\
\text { инициатив; } \\
\text { возможность получения } \\
\text { частного финансирования }\end{array}$ & $\begin{array}{l}\text { Создание } \\
\text { информационного } \\
\text { портала; } \\
\text { организация первого } \\
\text { краудфандингового } \\
\text { движения }\end{array}$ & $\begin{array}{l}\text { Отсутствие социально- } \\
\text { деловых инициатив среди } \\
\text { стейкхолдеров }\end{array}$ \\
\hline 2011-2016 гг. & $\begin{array}{l}\text { Масштаби- } \\
\text { рование } \\
\text { социальных } \\
\text { инициатив } \\
\text { и проектов }\end{array}$ & $\begin{array}{l}\text { Расширение границ } \\
\text { менторской, } \\
\text { инвестиционной помощи }\end{array}$ & $\begin{array}{l}\text { Развитие } \\
\text { конкурсного } \\
\text { и краудфандингового } \\
\text { движения }\end{array}$ & $\begin{array}{l}\text { Отсутствие } \\
\text { концептуального подхода } \\
\text { к формированию } \\
\text { законодательной базы }\end{array}$ \\
\hline $\begin{array}{l}2016 \text { г. } \\
\text { по настоящее } \\
\text { время }\end{array}$ & $\begin{array}{l}\text { Формиро- } \\
\text { вание } \\
\text { нормативно- } \\
\text { правового } \\
\text { регулирова- } \\
\text { ния } \\
\text { деятельности } \\
\text { СП }\end{array}$ & $\begin{array}{l}\text { Фрагментарное решение } \\
\text { отдельных вопросов } \\
\text { регулирования } \\
\text { деятельности СП }\end{array}$ & $\begin{array}{l}\text { Организация круглых } \\
\text { столов и форумов; } \\
\text { фундаментальные } \\
\text { и прикладные } \\
\text { исследования }\end{array}$ & $\begin{array}{l}\text { Нет единства в вопросах } \\
\text { формирования } \\
\text { социальной базы СП } \\
\text { и идентификации } \\
\text { субъектов; } \\
\text { отсутствие целостной } \\
\text { экосистемы СП, решение } \\
\text { лишь отдельных } \\
\text { вопросов развития СП }\end{array}$ \\
\hline
\end{tabular}

Источник. Авторская разработка.

нимательства в стране, - отсутствие возможности получения поддержки не только со стороны государства, но и со стороны частных бизнес-структур.

Tретий этап инфраструктурного развития социального предпринимательства правомерно связать с организацией конкурca «Social Weekend». Это конкурс социальных проектов и продвижения социальных идей, где участники получают социальные инвестиции, менторскую поддержку и проходят обучение. Обучение в рамках конкурса позволяет его участникам коммерциализировать свой проект, оценить степень социального влияния на стейкхолдеров, построить эффективную бизнес-модель. Организаторы конкурса ставят его главной целью увеличение числа субъектов, которые хотят реализовать социальные инициативы. Первый конкурс проектов был проведен в 2012 г., в 2019 г. организован 14-й конкурс «Social Weekend». За 8 лет существования проекта в нем приняло участие более 3500 уникальных проектов, в которые инвестировано около 750000 бел. руб. Далее в 2014 г. создана вторая краудфандинговая платформа «Талака», в 2015 г. - третья платформа «Улей». Данные платформы способствуют поиску единомышленников, партнеров и спонсоров для запуска социальных проектов и за период функционирования позволили реализоваться более 1000 проектам. Главной отличительной особенностью платформ является консультация коуча при подаче заявки, что помогает участникам сфокусироваться на создании бизнес-модели проекта, которая будет четко отвечать поставленным зада- 
чам. Реализация третьего этапа стала началом в продвижении основ социального предпринимательства через создание устойчивой бизнес-модели для достижения социальной цели деятельности организации. Социальная и экономическая интеграция знаний в области применения основ социального предпринимательства и управления им обеспечила узнаваемость и позитивное восприятие обществом этого явления.

Четвертый этап развития инфраструктурной поддержки субъектов социального предпринимательства в Республике Беларусь правомерно датировать 2016 г., что связано с ростом социальных инициатив, направленных на обучение социальному предпринимательству, поиском инвесторов, открытием новых рабочих мест, удовлетворением потребностей социально незащищенных групп населения. За 2016-2019 гг. проведены фундаментальные и прикладные исследования в области социального предпринимательства. В стране прошло 3 форума, посвященных этим вопросам. С 2017 г. стал активно обсуждаться вопрос о необходимости разработки законопроекта о социальном предпринимательстве. Развитие обучающих институтов, заинтересованность государства и частного сектора, инициатива граждан привели к значимому синергетическому эффекту в области продвижения социального предпринимательства на законодательном уровне. В результате был разработан проект Концепции Закона «О социальном предпринимательстве в Республике Беларусь», который в настоящий момент времени находится на этапе доработки и согласования. В законопроекте освещены следующие актуальные вопросы: трудоустройство социально уязвимых категорий граждан; осуществление социально значимой экономической деятельности; определение путей распределения прибыли для решения социальных проблем или удовлетворения социальных нужд. Появился ряд глубоких научных исследований проблемы социального предпринимательства в Республике Беларусь специалистами НИЭИ Министерства экономики Республики Беларусь, НИИ труда Министерства труда и социальной защиты населения Республики Беларусь и др.
Таким образом, повышенный интерес к социальному предпринимательству способствовал развитию инфраструктурной поддержки его субъектов. Отмечая наличие многих ее элементов, правомерно сделать вывод: в настоящее время она носит фрагментарный характер, так как охватывает отдельные аспекты развития социального предпринимательства (налогообложение существующих хозяйственных субъектов, применяющих труд инвалидов, регламентирование осуществления отдельных социальных выплат и др.). При этом единый документ, определяющий сущность социального предпринимательства, выделяющий виды и направления деятельности в национальной практике, отсутствует. Также нет ясности в понимании социальной базы социального предпринимательства и его отличий от предпринимательства и благотворительности. Данные обстоятельства свидетельствуют о необходимости формирования экосистемы социального предпринимательства в Республике Беларусь, нацеленной на комплексное сопровождение его развития, включая нормативно-правовое, методическое, институциональное обеспечение. Это создаст условия для динамичного развития социального предпринимательства и поддержки социально незащищенных слоев населения в стране.

\section{Динамика и структура социально незащищенных слоев населения в Республике Беларусь, особенности их поведения на рынке труда}

Одним из объективных факторов, способствующих появлению социального предпринимательства, является рост численности социально незащищенных слоев населения в Республике Беларусь, который включает разные категории населения. В этой связи важным теоретическим и практическим вопросом для нормативно-правовой поддержки развития социального предпринимательства является уточнение понятия «социально незащищенные слои населения» и конкретизация категорий, которые включаются в данную группу. В Республике Беларусь наравне с термином «социально незащищенные слои населения» достаточно часто используется термин «социально уязвимые слои населения». Однако в 
нормативно-правовых актах Республики Беларусь данный термин отсутствует, что приводит к неточности трактования и некорректности отнесения отдельных категорий граждан к данным слоям населения. Уточнение состава объектов социального предпринимательства позволит определить целевые аудитории и количественные границы участия $\mathrm{CHCH}$ в деятельности организации для получения определенных льгот и преференций.

В концепции МОТ «Достойный труд» ${ }^{3}$ определен состав СНCH, который включает в себя следующие категории граждан:

1) людей с ограниченными возможностями (инвалиды I, II, III группы);

2) людей, страдающих различными видами зависимости (наркологической, токсикологической, алкоголической), числящихся на учете в специализированных органах;

3) людей, больных ВИЧ/СПИД;

4) лиц пенсионного и предпенсионного возраста;

5) одиноких и многодетных родителей, воспитывающих несовершеннолетних детей, в том числе инвалидов;

6) беженцев и вынужденных переселенцев.

В Республике Беларусь в соответствии с конвенциями МОТ принята концепция Достойного труда, разработан перечень показателей Достойного труда, организовано

${ }^{3}$ URL: https://www.ilo.org/wcmsp5/groups/public/-europe/--ro-geneva/--sro-moscow/documents/generic document/wcms_312020.pdf их статистическое измерение. Приведенные факты подтверждают правомерность использования перечня $\mathrm{CHCH}$ согласно концепции Достойного труда в национальной практике. Однако, учитывая особенности данных категорий граждан и специфику их количественного измерения в стране, необходимо внести некоторые коррективы, что позволит более точно учесть национальную практику. Состав СНCH в Республике Беларусь целесообразно дополнить следующими категориями граждан:

1) граждане, вышедшие из мест лишения свободы;

2) воспитанники детских домов до 25 лет;

3) лица пенсионного и предпенсионного возраста с уточнением их возраста (для мужчин с 59 лет, для женщин с 54 лет).

Данная классификация граждан расширяет границы классификации $\mathrm{CHCH,} \mathrm{при-}$ меняемой MOT, добавляя в нее те категории граждан, которые имеют определенные барьеры для входа на рынок труда. Главной причиной расширения границ $\mathrm{CHCH}$ является сниженная конкурентоспособность данных категорий граждан на рынке труда, причем для каждой из них меры содействия занятости должны различаться (поскольку причины их уязвимости на рынке труда различны). Численность и структура СНСН в Республике Беларусь отражены в табл. 2.

Несмотря на то, что общая численность СНСН в Республике Беларусь снижается, их удельный вес в численности населения уве-

Таблица 2

Динамика численности социально незащищенных слоев населения в Республике Беларусь, тыс. чел.

\begin{tabular}{|c|c|c|c|c|c|c|c|c|c|c|}
\hline Численность & 2010 г. & 2011 г. & 2012 г. & 2013 г. & 2014 г. & 2015 г. & 2016 г. & 2017 г. & 2018 г. & $\begin{array}{c}\text { Удельный } \\
\text { вес, } \\
\text { \% в } 2018 \text { г. }\end{array}$ \\
\hline \multicolumn{11}{|c|}{ Динамика роста численности категории СНСН } \\
\hline $\begin{array}{l}\text { Инвалидов в возрасте } \\
18 \text { лет и старше }\end{array}$ & 43,994 & 47,417 & 57,493 & 55,973 & 56,78 & 59,786 & 60,031 & 59,964 & 60,015 & 2,23 \\
\hline ВИЧ-инфицированных & 1,069 & 1,196 & 1,223 & 1,533 & 1,811 & 2,305 & 2,391 & 2,468 & 2,353 & 0,09 \\
\hline Беженцев & 0,155 & 0,085 & 0,106 & 0,208 & 0,868 & 1,246 & 0,788 & 0,748 & 0,895 & 0,03 \\
\hline Пенсионеров & 2468,9 & 2486,9 & 2512,2 & 2537,3 & 2559,7 & 2592,8 & 2619,3 & 2593,7 & 2561,1 & 95,17 \\
\hline \multicolumn{11}{|c|}{ Динамика снижения численности категории СНСН } \\
\hline Детей-сирот & 4,356 & 4,199 & 3,345 & 2,95 & 2,765 & 2,848 & 2,254 & 2,369 & 2,26 & 0,08 \\
\hline $\begin{array}{l}\text { Людей с различными } \\
\text { видами зависимостей }\end{array}$ & 29,838 & 28,681 & 25,395 & 23,259 & 21,895 & 20,569 & 19,346 & 18,864 & 18,157 & 0,67 \\
\hline $\begin{array}{l}\text { Людей, совершивших } \\
\text { преступления }\end{array}$ & 74,1 & 66,3 & 53,0 & 49,8 & 49,9 & 53,1 & 51,6 & 47,7 & 46,4 & 1,72 \\
\hline Итого & 2622,412 & 2634,778 & 2652,762 & 2671,023 & 2693,719 & 2732,654 & 2755,71 & 2725,813 & 2691,18 & 100,00 \\
\hline
\end{tabular}

Источник. Авторская разработка по: URL: http://www.belstat.gov.by 
личивается (в 2018 г. он составил 29,01\%) (рис. 1).

Изучение динамики отдельных категорий $\mathrm{CHCH}$ в Республике Беларусь за 2010-2018 гг. позволило сделать следующие выводы:

численность инвалидов в совершеннолетнем возрасте увеличилась в 2018 г. по сравнению с 2010 г. на $36,42 \%$, ее доля в структуре $\mathrm{CHCH} \mathrm{составляет} \mathrm{2,23 \% ;}$

численность ВИЧ-инфицированных за исследуемый период увеличилась более чем в 2 раза, ее доля в структуре $\mathrm{CHCH} \mathrm{со-}$ ставляет 0,09\%;

численность беженцев увеличилась более чем в 7,35 раза, их доля в структуре СНСН составляет 0,03\%;

количество лиц пенсионного возраста в стране увеличивается невысокими темпами, однако численность данной группы остается самой значительной $(95,17 \%$ в структуре $\mathrm{CHCH}$;

несмотря на снижение численности детей-сирот и людей, страдающих разными видами зависимостей, почти в 2 раза, значение этих показателей остается видимым, их удельный вес составляет 0,08 и 0,67 соответственно.

Общей характеристикой СНСН является уязвимость их положения на рынке труда, что связано со сниженной индивидуальной конкурентоспособностью (Московская, Соболева, 2016. С. 107). Это обусловлено разными причинами, но общим является ограничение их возможностей, наличие специфических требований к организации труда и особенной мотивации для поиска работы (Ванкевич, Коробова, 2015. С. 180). Указанные обстоятельства объясняют научный и практический интерес к изучению особенностей поведения $\mathrm{CHCH}$ на рынке труда.

Одной из наиболее слабозащищенных групп граждан на рынке труда Беларуси являются инвалиды. Их ограниченные возможности могут проявляться в полной или частичной утрате способности передвижения, контроля за своим поведением, осуществления самообслуживания и др. При желании и возможности осуществлять трудовую деятельность проблема трудоустройства людей с инвалидностью возникает вследствие низкого образовательного и профессионального статуса, наличия психофизических особенностей. Данные обстоятельства ограничивают круг подходящих вакансий. В республике ведется активная интеграция людей с инвалидностью на рынок труда и в общество. Вопросами их трудоустройства занимаются «Белорусское общество глухих», «Белорусское товарищество инвалидов по зрению», «Белорусское общество инвалидов», «Республиканская ассоциация инвалидов-колясочников», «Белорусская ассоциация помощи детям-инвалидам и молодым инвалидам», государственная служба занятости и местные органы власти. Постановлением Совета Министров Республики Беларусь от 13 июня 2017 г. № 451 утвержден Национальный план действий по реализации в Республике Беларусь положений Конвенции о правах инвалидов на 2017-2025 годы, стратегической целью которого является создание правовых, организационных и институциональных условий для реализации норм Конвенции и прав инвалидов в Республике Беларусь ${ }^{4}$. Кро-

4 URL: http://pravo.by /upload /docs /op / C21700451_1497646800.pdf

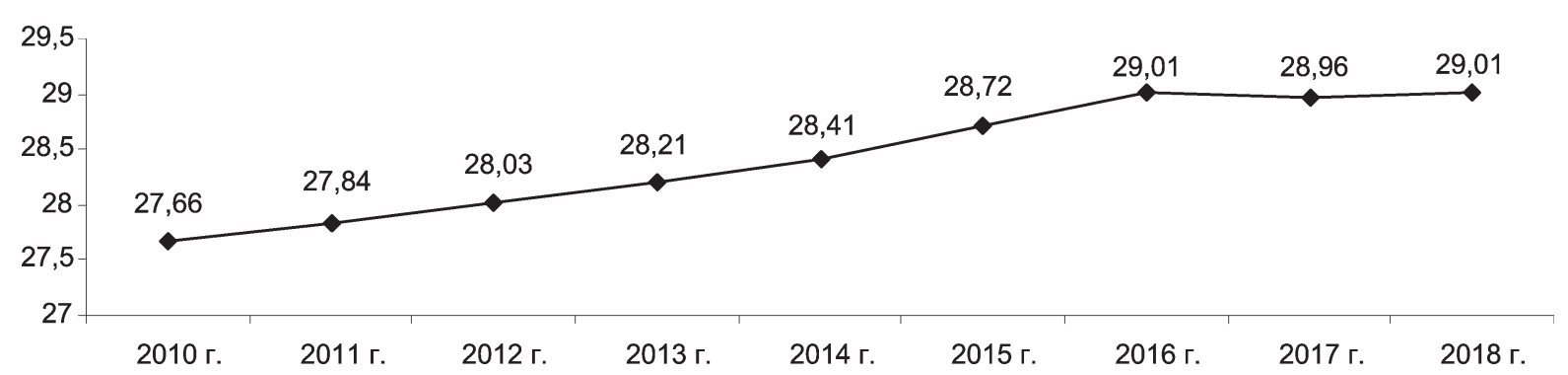

Рис. 1. Динамика удельного веса социально незащищенных слоев населения к общей численности населения в Республике Беларусь, \%

Источник. Авторская разработка по: URL: http://www.belstat.gov.by 
ме того, в стране есть инициативные организации (консалтинговое учреждение «Социальные технологии бизнеса», социальнопроизводственный комплекс объединения инвалидов «Равные возможности», арт-медиа проект «\#ЯПРИЕДУ»), которые также трудоустраивают людей с ограниченными возможностями.

Социальное предпринимательство создает дополнительные возможности для трудоустройства инвалидов. Следует отметить, что организации, которые содействуют занятости людей с ограниченными возможностями, имеют поддержку государства в виде налоговых преференций, финансовой помощи и т. д. ${ }^{5}$ На решение вопросов улучшения качества жизни инвалидов и их социальной интеграции в общество направлен ряд государственных программ. Так, Постановлением Совета Министров Республики Беларусь от 02.02.2009 г. (ред. от 22.10.2016 г.) № 128 «Об утверждении Положения о порядке финансирования и компенсации затрат на создание и сохранение рабочих мест для инвалидов и Положения о порядке организации и финансирования мероприятий по адаптации инвалидов к трудовой деятельности» утверждены порядок и правила компенсаций затрат, которые возникают у организаций, трудоустраивающих людей с ограниченными возможностями.

Анализ уровня занятости работающих инвалидов с учетом возрастных групп в Республике Беларусь (рис. 2) показывает, что категории от 20 до 49 лет достаточно активно вовлечены в трудовую деятель-

5 Жураковский В. 2017. Правовое регулирование социального предпринимательства в Республике Беларусь. URL: http://actngo.info/old/article/Social_enterprises

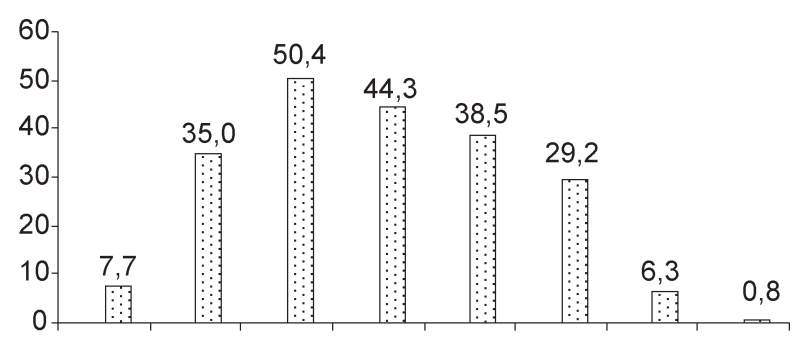

18-19 20-24 25-29 30-39 40-49 50-59 60-69 старше лет года лет лет лет лет лет 70 лет

Рис. 2. Удельный вес работающих инвалидов в общей численности инвалидов, в разрезе возрастных групп в 2018 г., \%

Источник. Авторская разработка по: URL: http:/ /www.belstat.gov.by ность (уровень занятости находится в диапазоне от 35 до 50,4\%).

Следует отметить: 60,9\% неработающих инвалидов в возрасте 18-19 лет обучались в различных учреждениях образования, 7,7\% были официально трудоустроены. Наиболее активны в трудоустройстве граждане с инвалидностью в возрасте от 25 до 29 лет (их доля составляет 50,40\%). В возрасте от 30 до 39 лет удельный вес работающих инвалидов составляет 44,30\%, в возрасте 40-49 лет 38,50\%. Среди молодых инвалидов 18-29 лет работают около 35\%. По данным НИИ труда Министерства труда и социальной защиты, в 2018 г. среди работающих инвалидов 54,7\% составили мужчины, 45,3\% - женщины ${ }^{6}$.

Определенные трудности на рынке труда испытывают лица пенсионного и предпенсионного возраста. В Беларуси проблема трудоустройства лиц пожилого возраста достаточно активно обсуждается на уровне правительства, принимаются различные меры для вовлечения пожилых граждан в социальную, культурную и образовательную сферы деятельности общества7. Повышенный интерес к вопросам интеграции и трудоустройства лиц пенсионного и предпенсионного возраста объясняется высоким удельным весом численности работающих пенсионеров в численности всех пенсионеров в Республике Беларусь (в 2018 г. он составил 24,9\%) (рис. 3).

Разработанная Национальная стратегия Республики Беларусь «Достойное

\footnotetext{
6 URL: http://www.instlab.by/index.php/deyatelnost/

7 URL: https:// forumpravo.by/ files /Proekt_ postanovlenie_SM_strategia_dolgoletia.pdf
}

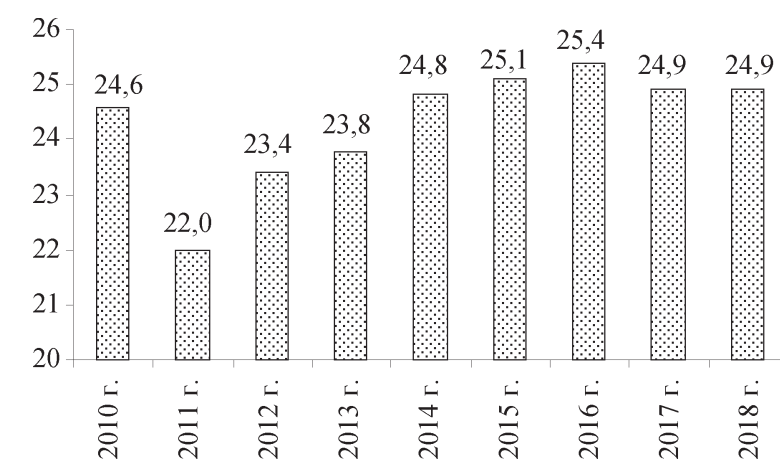

Рис. 3. Удельный вес численности работающих пенсионеров к общему числу пенсионеров в Республике Беларусь, \%

Источник. Авторская разработка по: URL: http:/ /www.belstat.gov.by 
долголетие-2030» предполагает совершенствование государственной политики в отношении трудоустройства пожилых граждан. Для преодоления барьеров, с которыми сталкивается данная категория граждан, предусмотрены изменение требований к ряду профессий и их специализаций; поддержка в развитии «возрастного» предпринимательства. Законодательное оформление деятельности института социального предпринимательства может решить ряд проблем трудоустройства людей пенсионного и предпенсионного возраста с учетом их интересов и профессиональных качеств.

В отношении людей, вышедших из мест лишения свободы и имеющих определенные виды зависимостей или отдельные заболевания, в обществе часто присутствует негативное восприятие, что формирует особую уязвимость таких лиц на рынке труда. Анализ статистических данных о динамике и трудоустройстве лиц, освобожденных из мест лишения свободы, показывает, что произошло снижение их численности с 74,1 тыс. чел. в 2010 г. до 46,4 тыс. чел. в 2018 г. Следует отметить уменьшение количества осужденных, которым была оказана материальная помощь в 2018 г. по сравнению с 2017 г., на 47 чел., или на 43,92\%. Количество осужденных в 2018 г., направленных на профессиональное обучение, составило 86 чел. и сократилось по сравнению с 2017 г. на 50\% ${ }^{8}$.

Согласно Постановлению Совета Министров Республики Беларусь «Об утверждении Положения о порядке организации и финансирования мероприятий по трудоустройству граждан, освобожденных из исправительных учреждений, в том числе частичной компенсации затрат по оплате труда таких лиц» ${ }^{9}$, для организаций предусмотрено финансирование мероприятий по трудоустройству освобожденных граждан, в том числе частичной компенсации затрат по оплате их труда. Так, за 2018 г. по данному Положению было трудоустроено только 23 чел. Предпринимаемые меры в этой области не могут ограничиваться только усилиями государственных органов и

${ }^{8}$ Кулагин Д.И., Кралько А.А., Костюченко Е.Л., Пугачева Н.С., Родионова Е.Н. 2019. Социальное сопровождение людей, вышедших из мест лишения свободы: методические рекомендации. Минск: ООО «Альтиора Форте». С. 12.

9 URL: https://registr.by/doc/1405314 должны активировать мотивацию работодателей при трудоустройстве людей, вышедших из мест лишения свободы. Такую задачу решает развитие социального предпринимательства.

Сложным является положение на рынке труда людей, страдающих разными видами зависимостей. В Республике Беларусь отсутствуют меры государственной поддержки для частных структур, трудоустраивающих данную категорию граждан. Препятствиями к их трудоустройству моиет быть низкий образовательный и профессиональный статус, возможность асоциального поведения и др. Многие лица совершают повторные преступления и возвращаются в места лишения свободы или лечения, увеличивая при этом налоговую нагрузку.

Проблема увеличения числа беженцев, в связи с дестабилизацией и политическими разногласиями в зарубежных странах, затрагивает как страны с неустойчивым положением, так и успешно развивающиеся. Беларусь не является исключением. Согласно статистическим данным, в период с 2010 по 2018 г. в миграционную службу Беларуси обратилось 5099 чел. (рис. 4).

В период с 2010 по 2013 г. в среднем в течение года обращались от 50 до 200 чел. Начиная с 2014 г. число беженцев резко увеличилось. Так, в 2015 г. их число составило 1246 чел., в 2017 г. - 748, в 2018 г. 895 чел. Наибольший поток беженцев наблюдается из Украины и Сирии. За статусом беженца за исследуемый период вре-

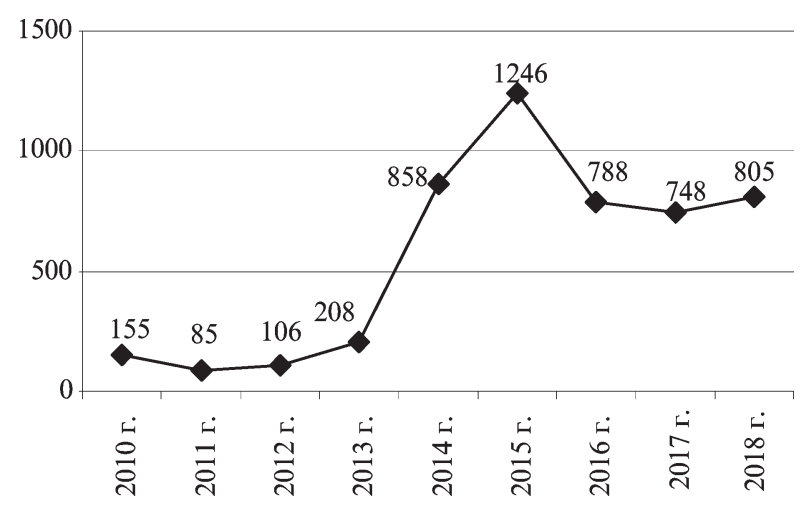

Рис. 4. Численность иностранцев, которые обратились с ходатайствами о предоставлении статуса беженца, чел.

Источник. Авторская разработка по:URL: http:/ /www.belstat.gov.by 
мени из Украины, в частности из Донецкой и Луганской обл., обратилось 2318 чел.

В Республике Беларусь функционирует проект УВКБ ОО и ОО «Белорусское движение медицинских работников» ${ }^{10}$. В рамках данного проекта проводятся встречи с беженцами, где поднимаются актуальные вопросы по получению медицинской и финансовой помощи, юридической поддержки и дополнительной защиты. Урегулированию жилищных и социальных проблем способствуют центры временного содержания беженцев. Языковые курсы для беженцев на безвозмездной основе проводят ряд учреждений образования и благотворительные некоммерческие организации. Таким образом, решению многих вопросов уделяется внимание как со стороны государства, так и со стороны общественных и образовательных заведений. Однако вопросами поиска рабочего места и трудоустройства беженцы должны заниматься самостоятельно. Следует учесть, что решение этих вопросов для них затруднено в силу обстоятельств:

во-первых, при получении иностранным гражданином статуса беженца его трудоустройство происходит наравне с иностранными гражданами, постоянно проживающими в Беларуси;

во-вторых, для трудоустройства иностранных граждан организации необходимо получать специальное разрешение в Департаменте по гражданству и миграции Министерства внутренних дел Республики Беларусь (срок его рассмотрения снижен для вынужденных мигрантов с 15 до 5 дней);

в-третьих, прием на работу данной категории граждан сопровождается определенными рисками, которые дополняются прохождением трудоемкой процедуры - получением разрешения на работу.

Исключение составляет трудоустройство граждан Российской Федерации, Республики Казахстан, Республики Армении, Кыргызской Республики, которым, согласно договору о Евразийском экономическом союзе, не требуется получения разрешения, т. е. при приеме на работу данной категории граждан нет ограничений по защите рынка труда в стране.

\footnotetext{
${ }^{10}$ URL: http://refugee.by/
}

Перечисленные обстоятельства затрудняют трудоустройство мигрантов и беженцев, что формирует не только риски превращения их в $\mathrm{CHCH} \mathrm{(включая} \mathrm{потерю} \mathrm{профессионализ-}$ ма, компетентности, уровня квалификации), но и криминализацию данных лиц.

Таким образом, проведенное исследование позволяет сделать вывод о том, что группировка $\mathrm{CHCH}$ является крайне неоднородной. Выявлена необходимость дополнения и уточнения представленных категорий, учитывая национальные особенности Беларуси. К числу СНСН правомерно добавить следующие категории граждан:

- вышедших из мест лишения свободы;

- воспитанников детских домов до 25 лет;

-лиц пенсионного и предпенсионного возраста с уточнением их возраста (для мужчин с 59 лет, для женщин с 54 лет).

Несмотря на снижение численности CHCH за 2010-2018 гг., их доля в общей численности населения страны остается достаточно значимой $(29,01 \%)$, а положение на рынке труда неоднозначным и уязвимым. Одни категории $\mathrm{CHCH}$ имеют физические барьеры для входа на рынок труда, другие эмоционально-психологические. Эти обстоятельства свидетельствуют о трудностях в трудоустройстве $\mathrm{CHCH}$, что подтверждает необходимость развития социального предпринимательства на основе формирования концептуального подхода и практических рекомендаций по его внедрению.

\section{Направления развития социального предпринимательства в Республике Беларусь}

Становление и развитие социального предпринимательства в Республике Беларусь предполагает выработку согласованных мер для формирования перспективной модели организационно-экономического механизма регулирования деятельности субъектов социального предпринимательства, т. е. формирования экосистемы развития социального предпринимательства.

В настоящее время разработан Проект Концепции Закона Республики Беларусь «О социальном предпринимательстве в Республике Беларусь» - он включает цели, задачи, определение сущности социального предпринимательства, обзор законодатель- 
ства, которое прямо либо косвенно его регулирует, оценку предложений заинтересованных государственных органов и иных организаций о необходимости законодательного закрепления института социального предпринимательства. То есть закон формирует базовые, рамочные условия для его развития. И сегодня представляется правомерным дополнить нормативно-правовые основы этого предпринимательства по следующим направлениям:

идентификация и сертификация его субъектов; ций;

разработка системы льгот и преферен-

оценка и контроль за деятельностью субъектов.

В совокупности реализация данных предложений позволит сформировать экосистему социального предпринимательства в стране, понимаемую как комплексную макросреду для его устойчивого функционирования.

Экосистемный подход к развитию предпринимательства в современном мире получил достаточно широкое распространение (Moore, 1993. Р. 77). Экосистема социального предпринимательства - это экономическое сообщество взаимосвязанных субъектов и институтов, выступающих катализатором взаимодействия участников через материальную и нематериальную составляющие с целью создания благоприятной среды для работы и жизнедеятельности СНСН. Создание такой экосистемы условно можно разделить на 2 составляющие: материальную и нематериальную. Материальная составляющая представляет собой сотрудничество государства и профильных структур по принятию закона, определению рамок финансовой поддержки и мер помощи субъектам социального предпринимательства, а также разработке единой методологии анализа, мониторинга и прогнозирования развития социального предпринимательства, ее методического, информационного обеспечения. Нематериальная составляющая экосистемы касается сложившихся особенностей общества в сфере социокультурных традиций, принципов и методов ведения бизнеса. Как правило, в странах с развитой предпринимательской культурой приветствуется социальная активность, а экосистема социального предприни- мательства может формироваться без помощи государства, т. е. без ее материальной составляющей. В Республике Беларусь развитие экосистемы социального предпринимательства невозможно без синергии материальной и нематериальной составляющих. Так, достаточно активная инфраструктурная поддержка института социального предпринимательства не позволила сформировать единого мнения о сущности социального предпринимательства, способах его идентификации и оценки результативности деятельности. Этапы формирования экосистемы представлены на рис. 5 .

Первый этап включает определение субъектов социального предпринимательства, критериев идентификации его субъектов, т. е. утверждение перечня качественных и количественных признаков.

Субъект социального предпринимательства - это организации или индивидуальные предприниматели, имеющие следующие признаки:

- наличие социальной проблемы, прописанной в учредительных документах, которая является первоочередной и превалирует над целью максимизации прибыли;

- регистрация в качестве юридического лица;

- предпринимательский подход и разработка бизнес-модели (коэффициент самофинансирования должен быть более 1);

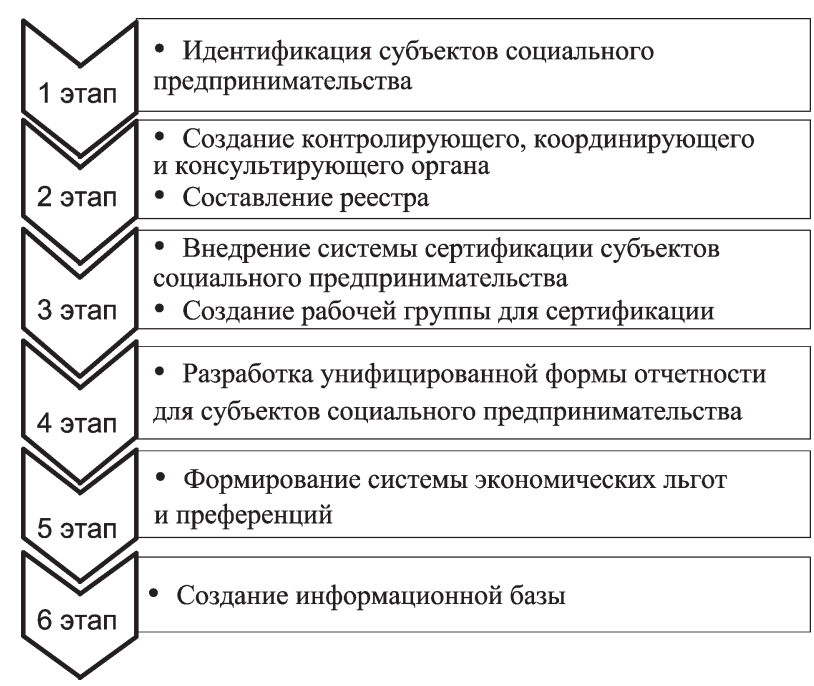

Рис. 5. Этапы формирования экосистемы развития социального предпринимательства в национальной практике Республики Беларусь

Источник. Авторская разработка. 
- наличие долгосрочной социальной миссии;

- реинвестирование прибыли - более $60 \%$ направлено на осуществление миссии организации;

- достойный уровень оплаты труда работников организации, включая социально незащищенные слои населения, при обязательной их доле в среднесписочной численности более $50 \%$ и доле заработной платы социально незащищенных слоев населения в фонде оплаты труда не менее 50\% при условии работы полный рабочий день.

Данные признаки позволяют точно определить субъект социального предпринимательства для оказания адресной поддержки объектам социального предпринимательства, к которым относят:

людей с ограниченными возможностями (инвалиды I, II, III группы);

людей, страдающих различными видами зависимости (наркологической, токсикологической, алкогольной), числящихся на учете в специализированных органах;

людей, больных ВИЧ/СПИД;

одиноких и многодетных родителей, воспитывающих несовершеннолетних детей, в том числе инвалидов;

беженцев и вынужденных переселенцев; граждан, вышедших из мест лишения свободы;

воспитанников детских домов до 25 лет;

лиц пенсионного и предпенсионного возраста с уточнением их возраста (для мужчин с 59 лет, для женщин с 54 лет).

Реализация второго этапа предполагает создание единого органа, отвечающего за два направления деятельности субъектов социального предпринимательства - социальное и экономическое. Основные задачи функционирования, которые ставят перед собой субъекты социального предпринимательства и Министерство труда и социальной защиты Республики Беларусь ${ }^{11}$, определенные в Положении о Министерстве труда и социальной защиты, имеют одинаковый вектор направленности. Однако, кроме социальной составляющей, в деятельности социального предпринимательства есть экономическая. Функции управления, координации и регу- лирования деятельности субъектов предпринимательства закреплены за Министерством экономики Республики Беларусь ${ }^{12}$. Наличие двойной направленности целевых ориентиров деятельности социального предпринимательства свидетельствует о необходимости создания органа, который будет сочетать функции Министерства труда и социальной защиты и Министерства экономики. При этом определение основных принципов функционирования социального предпринимательства позволило сделать вывод, что приоритетное направление его деятельности социальное, а экономическое является инструментом достижения. Исходя из вышесказанного, при создании органа по развитию социального предпринимательства прямое подчинение целесообразно закрепить за Министерством труда и социальной защиты населения.

Предполагаемое Управление по развитию социального предпринимательства должно осуществлять функции контроля и координации деятельности субъектов социального предпринимательства (рис. 6). Представленный проект структуры позволит эффективно взаимодействовать субъектам социального предпринимательства и органам управления: получать необходимую консультационную поддержку, координировать их действия и составлять отчетность для подтверждения права пользоваться льготами и преференциями.

Третий этап реализации концепции развития социального предпринимательства предполагает внедрение системы сертификации субъектов социального предпринимательства (как для функционирующих, так и для новых). Эта система будет включать прохождение определенных процедур, подтверждающих статус субъектов социального предпринимательства, для предоставления им права на получение льгот.

Признание статуса субъектов социального предпринимательства позволит: претендовать на получение льгот и преференций; повысить лояльность клиентов; увеличить значимость компании для органов власти; принимать участие в мероприятиях, организуемых для субъектов социаль-

\footnotetext{
11 URL: www.mintrud.gov.by/
}

\footnotetext{
12 URL: www.economy.gov.by/
} 


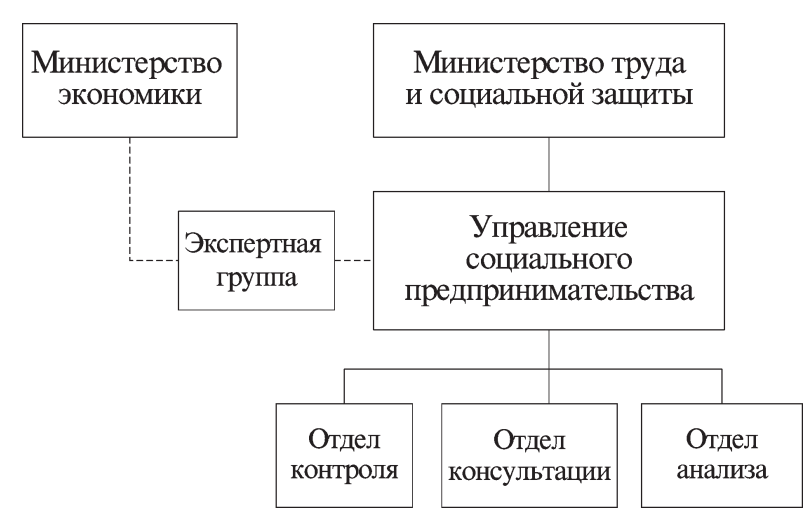

Рис. 6. Проект структуры Управления контроля и координации субъектов социального предпринимательства на национальном уровне

Источник. Авторская разработка.

ного предпринимательства; получать специальные предложения от партнеров.

Процедура сертификации субъектов социального предпринимательства должна проходить по единой методике (Ванкевич, Краенкова, 2018. С. 10).

Четвертый этап предполагает разработку формы отчетности для субъектов социального предпринимательства с целью оценки их деятельности, контроля обоснованности применения льгот и преференций. Данная форма отчетности ежеквартально предоставляется в отдел контроля в бумажном и электронном виде, заполняется по данным бухгалтерского баланса, приложений к нему, статистической и внутренней форм отчетности организации. Показатели в отчетности делятся на три группы: социальные, экономические и бюджетные. Для простоты определения вида и направленности деятельности субъектов социального предпринимательства разработана их кодировка через 4-значную систему, которая позволяет достаточно быстро идентифицировать деятельность организации, вектор ее направления и упростить систему анализа.

Реализация пятого этапа предполагает создание системы преференций. В Республике Беларусь существует ряд налоговых льгот при трудоустройстве людей с инвалидностью I и II группы, которые были рассмотрены выше. При трудоустройстве других уязвимых категорий граждан льготы не предусмотрены, что сдерживает развитие социального предпринимательства. Нацио- нальная система льгот при трудоустройстве людей с инвалидностью предполагает снижение процентных ставок при отчислении в фонд социальной защиты населения, освобождение от налога на прибыль и налога на добавленную стоимость. Однако она может быть дополнена рядом элементов (табл. 3).

Действующая система налогообложения до получения статуса субъекта социального предпринимательства предполагает систему льгот для людей с инвалидностью I и II группы при условии удельного веса этой категории в среднесписочной численности работников более 30\% (до 01.01.2020 г. среднесписочная численность должна была составлять $50 \%)$. В отношении участия остальных категорий граждан в деятельности субъектов социального предпринимательства преференций не предусмотрено. При успешном прохождении сертификации и получения статуса субъекта социального предпринимательства льготы по налогам и взносам на заработную плату будут получать все $\mathrm{CHCH}$, работающие в организации. Организации, подтвердившие этот статус, полностью освобождаются от налога на прибыль и налога на добавленную стоимость. Невыполнение требований, предъявляемых к субъектам, влечет за собой ответственность и лишение статуса субъекта социального предпринимательства.

Отдел контроля анализирует представленные данные бухгалтерской и статистической отчетности. В случае обнаружения незаконного применения льгот, невыполнения главных критериев для субъектов социального предпринимательства дело может быть направлено в суд.

Таким образом, предложенная система льгот и преференций для сертифицированных субъектов социального предпринимательства может стать эффективным инструментом его развития. Разработанная отчетность является формой контроля прогнозных показателей, гарантом их выполнения и выявления недобросовестных предпринимателей.

Для эффективного развития института социального предпринимательства необходима реализация шестого этапа - создание информационного реестра субъектов предпринимательства и его инфраструктурная 
Система налогообложения для субъектов социального предпринимательства

\begin{tabular}{|c|c|c|c|c|}
\hline \multirow{2}{*}{ Налог / взносы } & \multirow{2}{*}{$\begin{array}{c}\text { Нормативный } \\
\text { документ, статья }\end{array}$} & \multicolumn{2}{|c|}{$\begin{array}{c}\text { Процент отчислений } \\
\text { от налогооблагаемой базы } \\
\text { до получения статуса субъекта * }\end{array}$} & \multirow{2}{*}{$\begin{array}{c}\text { Процент } \\
\text { отчислений } \\
\text { от } \\
\text { налогооблагаемой } \\
\text { базы после } \\
\text { получения статуса }\end{array}$} \\
\hline & & $\begin{array}{c}\text { Люди с ограниченными } \\
\text { возможностями, I и II } \\
\text { группа инвалидности** }\end{array}$ & $\begin{array}{c}\text { Другие } \\
\text { категории } \\
\text { СНСН }\end{array}$ & \\
\hline $\begin{array}{l}\text { Взносы в фонд } \\
\text { социальной } \\
\text { защиты населения }\end{array}$ & $\begin{array}{c}\text { Закон Республики Беларусь } \\
\text { от 29.02.1996 г. «Об } \\
\text { обязательных страховых } \\
\text { взносах в бюджет государ- } \\
\text { ственного внебюджетного } \\
\text { фонда социальной защиты } \\
\text { населения Республики } \\
\text { Беларусь», ст. } 4\end{array}$ & 10 & $28+6+1$ & $6+1$ \\
\hline $\begin{array}{l}\text { Подоходный } \\
\text { налог }\end{array}$ & $\begin{array}{c}\text { Налоговый кодекс } \\
\text { Республики Беларусь, } \\
\text { П. } 1.3 \text { ст. } 164\end{array}$ & $\begin{array}{c}13 * * *+\text { дополнительные } \\
\text { вычеты }\end{array}$ & 13 & $9 * * *$ \\
\hline $\begin{array}{l}\text { Налог } \\
\text { на прибыль }\end{array}$ & $\begin{array}{c}\text { Особенная часть Налогового } \\
\text { кодекса Республики Беларусь, } \\
\text { п. } 4 \text { ст. } 181\end{array}$ & - & 18 & - \\
\hline $\begin{array}{l}\text { Налог при } \\
\text { упрощенной } \\
\text { системе } \\
\text { налогообложения }\end{array}$ & $\begin{array}{c}\text { Особенная часть } \\
\text { Налогового кодекса } \\
\text { Республики Беларусь, } \\
\text { гл. } 32 \\
\end{array}$ & $5 / 3$ & $5 / 3$ & - \\
\hline $\begin{array}{l}\text { Налог } \\
\text { на добавленную } \\
\text { стоимость }\end{array}$ & $\begin{array}{c}\text { Особенная часть Налогового } \\
\text { кодекса Республики Беларусь, } \\
\text { подп. } 1.16 \text { п. } 1 \text { ст. } 118\end{array}$ & - & $-/ 20$ & - \\
\hline $\begin{array}{l}\text { Налог } \\
\text { на недвижимость }\end{array}$ & $\begin{array}{c}\text { Особенная часть Налогового } \\
\text { кодекса Республики Беларусь, } \\
\text { подп. } 1.5 \text { п. } 1 \text { ст. } 228 \text { НК }\end{array}$ & - & 1 & - \\
\hline
\end{tabular}

* Налогооблагаемая база соответствует действующему законодательству Республики Беларусь.

** При условии, что среднесписочная численность инвалидов составляет более $50 \%$.

*** Стандартные налоговые вычеты сохраняются.

Источник. Авторская разработка.

поддержка. Единое информационное пространство позволит объединить справочные данные (наименование субъектов и их характеристика, основные показатели деятельности, график работы управляющего органа и пр.) по основным направлениям деятельности субъектов, о потенциальных субъектах и стейкхолдерах, по льготам и преференциям, событиям, конференциям и семинарам, связанным с социальным предпринимательством.

Последовательная реализация концепции развития социального предпринимательства в Республике Беларусь приведет к созданию единой экосистемы, учитывающей интересы всех участников, позволяющей четко определять субъекты социального предпринимательства, оказывать им информационную, методическую, налоговую поддержку, повышать экономическую активность СНСН и снижать барьеры при трудоустройстве. В совокупности это создаст условия для увеличения экономической и социальной отдачи от социального предпринимательства и его вклада в социальное развитие белорусского общества.

Таким образом, концепция развития социального предпринимательства в Республике Беларусь даст возможность законодательно определить новый сектор экономики «социальное предпринимательство», создать полноценно функционирующую экосистему его развития и информационную базу. Последовательная реализация представленных действий приведет к решению актуальных социальных проблем и достижению социальных целей, что является приоритетным направлением политики страны. Формирование экосистемы социального предпринимательства позволит расширить горизонт его 
деятельности, успешно развиваться и вносить весомый вклад в экономику страны.

\section{СПИСОК ЛИТЕРАТУРЫ (REFERENCES)}

Ванкевич Е.В., Коробова Е.Н. 2015. Оценка эффективности активных программ содействия занятости в регионе. Вестник Витебского государственного технологшческого университета. № 1(28). C. 174-185. [Vankevich A.V., Korobova A.N. 2015. Evaluating the effectiveness of active programs of employment in the region. Vestnik Vitebskogo gosudarstvennogo tekhnologicheskogo universiteta. No 1(28). PP. 174-185. (In Russ.)]

Зайцев В.В., Козел Т.А., Титок И.В. 2018. Социальное предпринимательство в Республике Беларусь и зарубежных странах: проблемы развития. Экономический бюллетень Научно-исследовательского экономического института Министерства экономики Республики Беларусъ. № 9. С. 4758. [Zaytsev V.V., Kozel T.A., Titok I.V. 2018. Social entrepreneurship in the Republic of Belarus and foreign countries: Development problems.
Ekonomicheskiy byulleten' Nauchno-issledovatel'skogo ekonomicheskogo instituta Ministerstva ekonomiki Respubliki Belarus'. No 9. PP. 47-58. (In Russ.)]

Ванкевич Е.В., Краенкова К.И. 2018. Социальное предпринимательство в современных условиях: сущность и методы оценки. Вестник Белорусского государственного экономического университета. № 2. C. 5-16. [Vankevich A.V., Krayenkova K.I. 2018. Social entrepreneurship under current circumstances: Essence and evaluation methods. Vestnik Belorusskogo gosudarstvennogo ekonomicheskogo universiteta. No 2. PP. 5-16. (In Russ.)]

Московская А.А., Соболева И.В. 2016. Социальное предпринимательство в системе социальной политики: мировой опыт и перспективы России. Проблемы прогнозирования. № 6. С. 103111. [Moskovskaya A.A., Soboleva I.V. 2016. Social entrepreneurship in the system of social policy: International experience and prospects of Russia. Problemy prognozirovaniya. No 6. PP. 103-111. (In Russ.)]

Moore J.F. 1993 Predators and prey: A new ecology of competition. Harvard Business Review. Vol. 71. No 3. PP. 76-86.

In citation: Belorusskiy Economicheskiy zhurnal. 2020. No 4. PP. 52-65.

Belarusian Economic Journal. 2020. No 4. PP. 52-65.

\title{
SOCIAL ENTREPRENEURSHIP: SOCIO-ECONOMIC BASES AND AREAS OF DEVELOPMENT IN THE REPUBLIC OF BELARUS
}

\author{
Elena Vankevich ${ }^{1}$, Kristina Krayenkova ${ }^{1}$ \\ Authors affiliation: ${ }^{1}$ Vitebsk State Technological University (Vitebsk, Belarus). \\ Corresponding author: Elena Vankevich (vankevich_ev@tut.by).
}

ABSTRACT. The article determines objective preconditions for social entrepreneurship development and sketches out stages of its infrastructural support in the Republic of Belarus. Socially vulnerable groups are considered to be social basis for such a development. Thus, changes in the number of the groups are studied to identify their behavior on the labor market. Looking at the results of this study, the lines for further social entrepreneurship development in the Republic of Belarus are worked out with the aim to create an effective social environment and advance its legal frameworks.

KEYWORDS: social entrepreneurship, socially vulnerable groups, social entrepreneurship ecosystem.

JEL-code: J1, J4, J7, H7.

DOI: $10.46782 / 1818-4510-2020-4-52-65$ 